\title{
PROBLEMS OF DETECTION AND IDENTIFICATION OF RADIO SIGNALS OF MEANS OF TACIT INFORMATION CONTROL
}

Vladimir I. Filatov,

DOI: $10.36724 / 2072-8735-2020-\mid 4-9-38-42$

Bauman Moscow State Technical University, Moscow, Russia, vfill0@mail.ru

Yevgeny N. Khokhlachev, Military Academy of Strategic Rocket Troops after Peter the Great, Balashikha, Moscow region, Russia,

khokhlach@mail.ru

Yaroslav B. Zaychenko, Military Academy of Strategic Rocket Troops after Peter the Great, Balashikha, Moscow region, Russia, jar05lav@yandex.ru

Manuscript received 24 June 2020; Accepted 07 September 2020

Valery I. Volokhov, Military Academy of Strategic Rocket Troops after Peter the Great, Balashikha, Moscow region, Russia, val.volohov@yandex.ru

Keywords: radio-technical aids, radio emission, signal, search device, receiver, demodulation

\begin{abstract}
In article discussed 4 aspects of signal reception such as information, power, time, space. The main point in the information aspect is the possibility to determine whether the received signal belongs of special radio-technical aids (SRTA), according to the availability of relevant content in the received message. The article gives examples of automated complexes and scanners and field indicators, realizing the phenomenon of "acoustic tie". It is noted that the presence of demodulation variants is not necessary for efficient signal detection SRTA. In general, it is proposed to represent a signal from the SRTA as a signal with a random basis in the time and frequency domain without taking into account the method of its generation. The fast signal detection parameters are specified when using tuning receivers [I]. The article justifies the influence of the energy aspect to solve the problem of detecting signals from the SRTA. The problem with artificial application of restrictions to limit values of SRTA parameters is also considered. Disclosed is a method of solving said problem. In the article the general scheme of tacit information control is executed. The article also provides conditions for the possibility of effective detection of a signal with unknown properties. The inventors justify the use of the radio emission of SRTA transmitters as an active feature, which can be optimized by the structure of searchers depending on the model of the detected signal, as well as depending on the conditions of the control point. You have identified factors that allow you to optimize your search engines.
\end{abstract}

Information about authors:

Vladimir I. Filatov, candidate of technical Sciences, associate Professor at the Bauman Moscow State Technical University, faculty of Informatics and control systems, Department of information protection, Moscow, Russia

Yevgeny N. Khokhlachev, doctor of technical Sciences senior research associate of the Military Academy of Strategic Rocket Troops after Peter the Great, Balashikha, Moscow region, Russia;

Yaroslav B. Zaychenko, adjunct of the Military Academy of Strategic Rocket Troops after Peter the Great, Balashikha, Moscow region, Russia Valery I. Volokhov, teadur, adjunct of the Military Academy of Strategic Rocket Troops after Peter the Great, Balashikha, Moscow region, Russia

Для цитирования:

Филатов В.И., Хохлачев Е.Н., Зайченко Я.Б., Волохов В.И. Проблемы обнаружения и идентификации радиосигналов средств негласного контроля информации // Т-Сотm: Телекоммуникации и транспорт. 2020. Том I4. №9. С. 38-42.

For citation:

Filatov V.I., Khokhlachev Y.N., Zaychenko Y.B., Volokhov V.I. (2020) Problems of detection and identification of radio signals of means of tacit information control. T-Comm, vol. I4, no.9, pp. 38-42. (in Russian) 
Systems of detection and identification of radio-frequency range signals are currently among the most widespread devices, used in case of counteraction to tacit information control. Such devices are implemented in the form of broadband indicators of electromagnetic field, scanners and automated radio monitoring complexes on the bases of digital receivers. All they are based on presence of evident enabling sign of work of special radiotechnical aids (SRTA) in the form of radio emission which exists while switching on the SRTA in transmission mode.

In case of detection of radio signals the main requirement is guaranteed identification of received radio emission as 'dangerous', which makes the task to optimize the structure and parameters of radio signal detection devices vital. Guaranteed detection and identification of the SRTA signals are possible in case of implementation of certain conditions, determining the following aspects of signal receiving [2]:

Information;

Power;

Time;

Space.

On first approaching all these aspects are independent on each other, which allows to view their influence on structure and technical properties of radio signal detection devices separately.

Information aspect is mainly used to identify SRTA signals among numerous interfering signals from external and extraneous stations, as well as to determine broadcast transmissions. The main point in the information aspect is the possibility to determine whether the received signal belongs to SRTA according to the presence of corresponding informational content in the received message. As a possible class of information message, as a rule, speech signal existing in one or several controlled rooms is examined [3]. For that purpose most of receiving complexes and aids allow to perform demodulation of a signal by standard procedures, provided by the receiver (AM, FM, PM etc.), as well as to use additional options of identification in the form of presence of correlation between demodulated signal and acoustic signal of a room. Moreover, such procedures allow to solve both automated complexes and scanners and field indicators, realizing the phenomenon of «acoustic tie». Among the existing devices «RICH-2», «RICH-3», «D-006», «D-008», «IPSH-012» field indicators, «Oscor-5000», «Xplorer», «Cub», «Scorpion» scanners, and «APK», «RCC-2000», «Rodea» automated complexes should be noted [4].

While not denying the usefulness of this procedure for most practical tasks the limitation of solution for SRTA variants should be noted, as they don't foresee analogue types of modulation, are not appropriate to intercept speech information, and use complex types of modulation, coding and screening. Considering the perspectives of development of information transmission techniques, including SRTA, as well as theoretical methods of applying the systems of noise-like signals, the opportunity of signal identification by information indications reduces to minimum.

Currently, the signal emitting SRTA should be examined as noise-like, which excludes opportunities of its demodulation without knowing the method of source information transformation [5]. Moreover, the presence of demodulation options is not necessary for effective detection of SRTA signals.

In general the signal from SRTA can be presented as a signal with random base in time-and-frequency area without taking the method of its forming into consideration [6]. Currently, the sig- nals with random base, to some extent, are realized while using the signals with operating frequency pseudorandom hopping $(\mathrm{OFPH})$ and using the method of compression of signal in time. From the positions of counteraction the limitation of types of bases of the received and identified signals leads to uncertainty of assessment of search devices capability in relation to appearing and realizing types of signals.

The existing search devices and complexes are aimed to detect and identify continuous signals or type of fast signals if SRTA will include remote control. Capability of search devices to detect signals with OFPH is determined by certain parameters of signals, i.e. by channel switching rate, quantity of these channels, and each channel band width. The problem of detection and identification of signals with OFPH is self-consistent and should be solved with use of specialized radio receivers with high frequency tuning rate [7].

The capability of detection of fast signals while using tuning receivers depend on its tuning rate in comparison with signal frequency change rate, however, long-lasting analysis of frequency range makes the probability of detection of such a signal approaching 1 [8].

A signal with random base is characterized by random appearing of radio emission in arbitrary frequency range section. Obviously, the correct identification of such a signal by traditional methods is extremely difficult. Examination of SRTA signal as noise process allows to build detecting aids or complexes optimally. For that situation, energetic receivers like radiometers, known in radio engineering, which use for the given task has several specific moments, which will be analyzed in the next article, will be optimal.

Power aspect in solving the task of detection of SRTA signals represents determination of requirements for component parts of radio monitoring aids, taking sensitivity of the receiver, emission power and conditions of SRTA location into account. Obviously, while having artificially applied limitations for limiting values of SRTA parameters the solution of detection task will have threshold nature, which will consequently significantly decrease potential efficiency of detection systems. This problem may be solved without using power properties. For that purpose we'll review the generalized chart of tacit information control, presented in fig. 1.

As a model of tacit information control it is rational to examine the situation of optimal SRTA signal reception at the control point, i.e. organization of coherent reception, the distance $\mathrm{L}_{\mathrm{k}}$ and attenuation of the signal, caused by the building structure, into consideration [9].

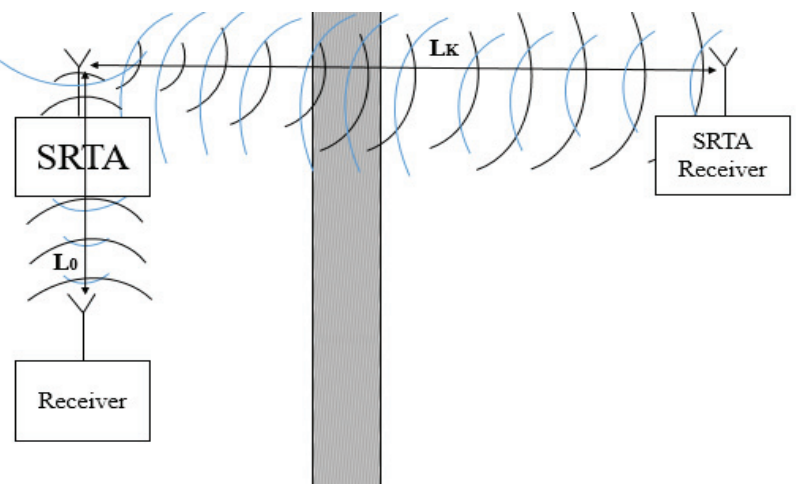

Fig. 1. Signal radio control diagram of SRTA 
The recept of SRTA signal by the detection receiver is apparently incoherent, as the properties of this signal are unknown, and opportunities of effective detection are determined by the following conditions:

distance $\mathbf{L}_{\mathbf{k}}$ longer than distance $\mathbf{L}_{\mathbf{0}}$ at which antenna detection device is placed;

SRTA signal is additionally attenuated by the building constructions along the radio path.

If SRTA is optimally calculated, the power of the signal at inputs of both receivers can be linked with each other by means of the transmitter radio range and the transmitter emission power [10]. While using known expressions for radio channel simple correlation between distances $\mathbf{L}_{\mathbf{k}}$ and $\mathbf{L}_{\mathbf{0}}$ in the following form may be obtained:

$$
L_{0}=\frac{L_{K}\left[\Phi\left(1-\mathrm{F}_{K}\right)-\Phi\left(1-\mathrm{D}_{K}\right)\right]}{\alpha^{2} \sqrt{\frac{\ln F_{0}}{\ln D_{0}}-1}}
$$

where $\Phi(\mathrm{x})$ indicate quantile function of normal distribution; $\alpha^{2}$ attenuation in power added to the signal by the building construction; $F_{k}$ and $D_{k}$ - probability of false alarm and correct detection for detection receiver.

The formula is obtained for the following conditions assuming identity of radio wave propagation along the paths to both radio receivers:

the receiver at the control point performs coherent analysis;

the detection receiver performs incoherent analysis; attenuation of the radio signal by the building constructions is determined by multiplier $\alpha^{2}$, which is frequencydependent for constructions of different type $(\alpha<1)$.

Thus, the requirements to location of SRTA signals detection devices may be determined only out of certain normative considerations and specific conditions at the object of control without taking power indices of SRTA radio transmitter into account [11]. The selection of certain probability values of false alarm and correct detection for both receivers is determined by requirements to quality of the signal recept and can be made out of the following assumptions:

probability of false alarm $\mathrm{F}_{\mathrm{k}}$ for SRTA receiver can be selected of order $10^{-3} \ldots 10^{-2}$, as the situation of false recept for tacit control is not significantly dangerous;

probability of false alarm for the detection receiver $F_{0}$ should be significantly lower, of order $10^{-8} \ldots 10^{-10}$, as the false recept in the given case is crucial and leads to additional expenses for decoding false responses;

probability of correct detection of the signal $D_{k}$ for SRTA receiver should be high enough, of order $0.9 \ldots 0.99$, as the guaranteed recept of the signal is the main requirement to systems of tacit information control;

probability of correct detection $\mathrm{D}_{0}$ can be selected of the same order $0.9 \ldots 0.99$, as the requirement of guaranteed detection of the unknown signal should be examined as principal.

In order to vary the given values of normative parameters $\left(F_{k}\right.$, $\mathrm{F}_{0}, \mathrm{D}_{\mathrm{k}}, \mathrm{D}_{0}$ ) correlation between the distances $\mathbf{L}_{\mathbf{k}}$ and $\mathbf{L}_{\mathbf{0}}$ leads to the following form:

$\mathrm{L}_{0}=(0,075 . .0,3) \frac{\mathrm{Lk}}{\alpha}$
In case of extreme situation, when the signal attenuation values, brought by building constructions, are unknown it is rational to select $\alpha=1$ and to determine the distance on the basis of simple correlation $\mathrm{L}_{0}=(0,075 . .0,3) \mathrm{L}_{\mathrm{k}}$. Attenuation ratio caused by building constructions is insignificant for the frequencies of traditional VHF and UHF range, used to transmit the signals from SRTA, and makes the selection of coefficient $\alpha=1$ appropriate; moreover, the case of signal attenuation by constructions in route $\mathrm{L}_{0}$ cannot be excluded, which removes the problem of assessment of signal attenuation impact on detection devices parameters selection.

Reduction of distance $\mathrm{L}_{0}$ in comparison with distance $\mathrm{L}_{\mathrm{k}}$ is a "price to pay" for the uncertainty of the signal parameters. For the most stringent requirements the distance between the antenna of the detection device and the antenna of the assumed SRTA transmitter should amount to not more than 0,075 of the distance between the transmitter and the SRTA receiver. For instance, while having the distance of 100 meters to the place of possible location of SRTA control point, allocation of antennas of the detection device should be organized in such a way in order to make the distance from the antenna of the required radio transmitter to the antenna of the detector not more than 7.5 meters, i.e. the distance between the antennas (or positions of the antennas) should be not more than 15 meters. In case of shorter distances to the control point, the problem of the detection device antennas allocation becomes hard to solve practically [12].

From positions of power, the operating principle of detection devices of electromagnetic field indicators type has certain advantages, as while shifting along the examined area, the required or shorter distance between antennas of radio transmitter and indicator is achieved (however, it should be taken into consideration, that SRTA model for indicators of the field is bounded, in case of necessity of SRTA operation in the mode of emission on examination, moreover, the indicator is hyposensitive depending on the difference of its band of operative frequencies in comparison with the signal bandwidth).

Stationary automated complexes are currently equipped with the system of receiving antennas (for instance, complexes of "APK" series), which allows to provide the detection of the signal in several rooms. Considering the developed requirements, the number of receiving antennas of the complex can be determined depending on the assumed distance to the possible control point.

For standard situations, this number is not so significant, as the distance of 15 meters assumes installing them approximately across the room of 5-6 meters wide. In case of shorter distances to the control point (15-20 meters) optimal use of standard complexes of radio control becomes problematic, as the distance between the receiving antennas in this case should be not more than 3 meters, which increase the required number of antennas almost 30 times.

Space aspect implies the assumed availability of the directional response of the SRTA transmitter antenna, considering the allocation of the control point. While estimating the impact of the power aspect, it was assumed, that the receiving control and detection antennas work in identical conditions. In conventional VHF and UHF frequency range, forming the directional response of mini-antennas is problematic, and usually the antenna represents a dipole with a circular pattern. While increasing SRTA frequency range such a possibility becomes more real, for in- 
stance, by using not dipole, but vibrator antennas, allowing to provide certain direction. The most significant thing is non-zero probability of unsuccessful allocation of the receiving detection antennas in corner areas with minimum emission in the required direction. Consideration of the directional responses significantly worsen the requirements to minimal distance of detection antenna to transmitter antenna. Moreover, in microwave frequency range it can lead to a difficult situation of necessity of allocation of receiving antennas on exterior surfaces of buildings from the side of control point location.

Time aspect implies the necessity of coincidence of the SRTA transmitter operating time in emission mode and settings of the detection receiver on the corresponding frequency range. We know, that for signals with random base or short-term sending, as well as SRTA with external control, such a coincidence may be stochastic. Searching devices according to this factor can be divided into 2 groups:

electromagnetic field indicators and scanners, which assume the required signal emission continuity during the researches;

stationary complexes of detection, intended for a continuous monitoring of the signals in a frequency range.

The first group of searching devices is intended to detect the emission of SRTA of continuous operation, which currently represent rather vast class of means of tacit information control. Both problems of power and space aspects to some extent can be solved by shifting such searching devices. For the received model of signal such searching devices are practically optimal on the principle of operation.

The second group of searching devices is intended to detect SRTA signals of wider class, and the main problem is correspondence of requirements to the tuning time of detection receivers with possible models of time parameters of SRTA. Possible approach to development of requirements of the receivers tuning rate will be examined in the following articles.

However, on the basis of general considerations it may be stated, that in case of infinitely long time of monitoring for the signal in the controlled frequency range, the SRTA signals with arbitrary characteristics of emission in time, including short-term sending or signals with OFPH, will be definitely detected.

Thus, the use of radio emission of SRTA transmitters as enabling sign, may be optimized both by the structure of searching devices depending on the model of the detected signal, and depending on the conditions of location of the control point. In such case main factors allowing to perform optimization of the searching devices are:

orientation to SRTA signal as to a signal with a random base, i.e. noise process, which demodulation has no sense within the framework of solving task of counteraction to tacit information control; in case of detection of SRTA signals, which are optimally developed, the antenna (antennas) of detection devices should be located at certain minimal distance to the antenna of the searched SRTA receiver;

searching aids of type of electromagnetic field wide band indicators and scanners may be used to detect the signals of SRTA, operating in continuous radiation mode, provided they were shifted in space in order to reach minimal distances between antennas of the searching device and receiver;

automated stationary radio monitoring complexes allow to detect radio signal of SRTA of wider class with arbitrary types of SRTA operating mode control, however, they demand definition of requirements to the applicable base receivers frequency tuning rate.

While using special equipment of searching and detection aids and complexes available on the market in practice in certain situations, one should have clear vision of SRTA signals models, subject to detection, or a consultation of a specialist for optimization of building of signal detection systems with regard to the conditions of the protected object dislocation.

\section{References}

1. Anpilogov V.R. (2015). Efficiency of low-orbit satellite communication systems on the basis of small spacecrafts. Technologies and means of communication. No. 4. P. 62-66.

2. Filatov V., Borukaeva A., Berdikov P. Kulakov D.V. (2019). Development of methods for distinguishing complex noise-resistant signals. Trudy MAI. No. 105, Moscow: april - 2019. http://trudymai.ru/published.php?ID=104188.

3. Korobchak A.V., Nekrasov A.S., Berdikov P.G. (2019). Method of construction constellations satellite communication system. T-Comm. Vol. 13. No.11.

4. Davydov G.B.(1984). Information and communication networks. Moscow: Nauka.

5. Menshikov Yu.K. (2002). Protection of objects and information from TSR. Moscow: Russian humanitarian University. 399 p.

6. Filatov V.I. (2017). Prospects for the development of REWM tools / Special communication and information security: technologies, management, Economics. Proceedings Of the 3rd International scientific Symposium. Publishing house: Resins.

7. Hoffman L.J. (1991). Modern methods of information. Moscow: Sov. Radio.

8. Grishina N.V. (2007). Organization of a complex information security system. Moscow: Helios ARV. 256 p.

9. Tuzov, G.I., Sivov V.A., Prytkov V.I. et al. (1985). Jamming Protection of radio systems with complex signals. Moscow: Radio and communications. $264 \mathrm{p}$.

10. Kulikov, G.V. (2003). Noise Immunity of modulated signal receivers with continuous phase in the presence of non-fluctuating noise // Radio Engineering. No. 7, pp. 21-25.

11. Borisov V.I. (2009). Jamming Protection of radio communication systems: fundamentals of theory and principles of implementation. Moscow: Nauka. 358 p.

12. Varakin L.E. (1970). Theory of complex signals. Radio. 376 p. 


\section{ПРОБЛЕМЫ ОБНАРУЖЕНИЯ И ИДЕНТИФИКАЦИИ РАДИОСИГНАЛОВ СРЕДСТВ НЕГЛАСНОГО КОНТРОЛЯ ИНФОРМАЦИИ}

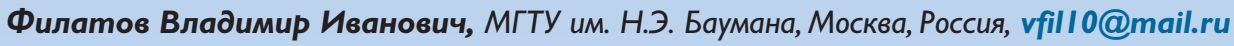

Хохлачев Евгений Николаевич, ВА РВСН им. Петра Великого, Россия, Московская область, Балашиха, Poсcия, khokhlach@mail.ru Зайченко Ярослав Борисович, ВА РВСН им. Петра Великого, Россия, Московская область, Балашиха, Poccuя, jar05lav@yandex.ru Волохов Валерий Иванович, ВА РВСН им. Петра Великого, Россия, Московская область, Балашиха, val.volohov@yandex.ru

\section{Аннотация}

Рассмотрено четыре аспекта приема сигнала такие как: информация, мощность, время, пространство. Выделен основной момент в информационном аспекте - возможность определения, принадлежит ли принятый сигнал от специальных радио-технических средств (СРТС), согласно наличию соответствующего информационного содержания в принятом сообщении.Приведены примеры автоматизированных комплексов, сканеров и полевых индикаторов, реализующих феномен "акустической связки". Отмечено, что наличие вариантов демодуляции не является необходимым для эффективного обнаружения сигналов СРТС. Предложено в общем случае сигнал от СРТС представлять как сигнал со случайным базисом в области времени и частоты без учета способа его формирования. Указаны параметры обнаружения быстрых сигналов при использовании настроечных приемников. Обосновано влияние энергетического аспекта для решения задачи обнаружения сигналов от СРТС. Также рассмотрена проблема при искусственном применении ограничений для ограничения значений параметров СРТС. Предложен способ решения указанной проблемы. В статье казана обобщенная схема негласного информационного контроля. Также в статье приведены условия возможности эффективного обнаружения сигнала с неизвестными свойствами. Выведена формула для условий, предполагающих идентичность распространения радиоволн по трактам к обоим радиоприемникам. Авторы обосновывают использование радиоизлучения передатчиков СРТС в качестве активного признака, который может быть оптимизирован структурой поисковых устройств в зависимости от модели обнаруженного сигнала, так и в зависимости от условий расположения контрольной точки. Определены факторы, позволяющие выполнять оптимизацию поисковых устройств.

Ключевые слова: радиотехническое средство, радиоизлучение, сигнал, поисковое устройство, приемник, демодуляция.

\section{Литература}

І. Анпилогов В.Р. Эффективность низкоорбитальных систем спутниковой связи на основе малых космических аппаратов // Технологии и средства связи. 20I5. № 4. С. 62-66.

2. Филатов В.И., Борукаева А.О., Бердиков П.Г., Кулаков Д.В. Development of methods for distinguishing complex noise-resistant signals // Trudy MAI №105. М.: Апрель - 2019 г. http://trudymai.ru/published.php?ID=104188;

3. Коробчак А.В., Некрасов А.С., Бердиков П.Г. Методика построения орбитальных группировок систем спутниковой связи // Т-Сотт. Т. І3. No. II-2019.

4. Давыдов Г.Б. Информация и сети связи. М.: Наука, 1984;

5. Меньшиков Ю.К. Защита объектов и информации от ТСР. М.: Российский гуманитарный университет. 2002, 399 с.

6. Филатов В.И. Перспектива развития средств РЭБ / Специальная связь и безопасность информации: технологии, управление, экономика // Сборник трудов 3-ого Международного научного симпозиума. Издательство: Русайнс, 2017.

7. Хоффман Л. ДЖ. Современные методы информации / Пер.с англ.М.: Сов. радио, 1991.

8. Гришина Н.В. Организация комплексной системы защиты информации. М.: Гелиос АРВ, 2007. 256 с.

9. Тузов Г.И., Сивов В.А., Прытков В.И. и др. Помехозащищенность радиосистем со сложными сигналами. М. : Радио и связь, 1985.264 с.

І0. Куликов Г.В. Помехоустойчивость приемников модулированных сигналов с непрерывной фазой при наличии нефлуктуационных помех // Радиотехника. 2003. № 7. С. 21-25.

II. Борисов В.И. Помехозащищенность систем радиосвязи: основы теории и принципы реализации. М.: Наука, 2009. 358 с.

12. Варакин Л.Е. Теория сложных сигналов. М.: Сов. радио, 1970. 376 с.

Информация об авторах:

Филатов Владимир Иванович, к.т.н., доцент кафедры МГтУ им. Н.Э. Баумана факультета "Информатика и системы управления", кафедры "Защита информации", Москва, Россия

Хохлачев Евгений Николаевич, д.т.н., старший научный сотрудник ВА РВСН им. Петра Великого, Московская область, Балашиха, Россия Зайченко Ярослав Борисович, адьюнкт ВА РВСН им. Петра Великого, Московская область, Балашиха, Россия

Волохов Валерий Иванович, научный сотрудник, адьюнкт ВА РВСН им. Петра Великого, Московская область, Балашиха, Россия 